\title{
SPECTRAL REFLECTANCE OF IPÊ-AMARELO LEAVES UNDER DIFFERENT FORMS OF STORAGE AND COLLECTION TIME
}

\author{
Juliana Tramontina ${ }^{1}$, Pâmela Suélen Käfer ${ }^{1}$, Tássia Fraga Belloli ${ }^{1}$, Denise Cybis Fontana ${ }^{1}$ \\ ${ }^{1}$ Graduate Program in Remote Sensing, State Center of Research in Remote Sensing and Meteorology, Federal University of Rio Grande do \\ Sul (UFRGS), Porto Alegre, Rio Grande do Sul, Brazil - tramontina.ju@gmail.com, pamelaskafer@gmail.com, tassiabellolif@gmail.com, \\ dfontana@ufrgs.br \\ Received for publication: 12/12/2017 - Accepted for publication: 30/07/2018
}

\begin{abstract}
The application of spectroradiometry techniques to the study of tree species allows the acquisition of information related to plant physiology and morphology, which can be used in conjunction with orbital images. However, it is known that when a leaf is extracted the senescence process is started, which is characterized by cell constituents degradation, loss of water and modifications of the foliar mesophyll structure. In this context, this study aimed to evaluate the influence of the collection time and storage form on the spectral response of ipê-amarelo leaves. Thus, 32 leaves were collected in distinct times (1h, 2h, 24h and 48h) and conditioned with $(C)$ and without(S) thermal storage. The data were evaluated from the visual analysis of the spectral curves, derivative analysis and statistical analysis. The experiment was conducted in a Randomized block design and data were submitted to analysis of variance (ANOVA) and Tukey test $(\mathrm{p}=0.05)$. Results indicated that thermal storage might delay the senescence process of the leaves. Both the collection time and the storage form affect the pattern of spectral behavior of the leaves of ipê-amarelo. The collection time has not shown significant differences between 1-2h. The largest differences were found between 2-24h after collection.
\end{abstract}

Keywords: Spectroradiometry; Spectral Response; Tree Specie; Derivative analysis.

\section{Resumo}

Reflectância espectral de folhas de ipê-amarelo sob diferentes formas de armazenamento e período de coleta. A aplicação de técnicas de espectrorradiometria para o estudo de espécies vegetais possibilita a obtenção de informações relacionadas a fisiologia e morfologia da planta que podem ser utilizadas em conjunto com imagens orbitais. Contudo, sabe-se que quando uma folha é extraída, o processo de senescência é iniciado, o qual é caracterizado pela degradação dos constituintes celulares, perda de água e modificações da estrutura do mesófilo foliar. Neste contexto, este estudo objetivou avaliar a influência do período de coleta e a forma de armazenamento na resposta espectral de folhas de ipê-amarelo. Assim, 32 folhas da espécie foram coletadas em períodos distintos ( $1 \mathrm{~h}, 2 \mathrm{~h}, 24 \mathrm{~h}$ e $48 \mathrm{~h}$ ) e acondicionadas com e sem armazenamento térmico. Os dados foram avaliados a partir da análise visual das curvas espectrais, análise derivativa e estatística. $\mathrm{O}$ experimento foi conduzido com delineamento estatístico em blocos ao acaso e os dados submetidos à análise de variância (ANOVA) e teste Tukey $(\mathrm{p}=0,05)$. Os resultados indicam que o armazenamento térmico pode retardar o processo de senescência das folhas. Tanto o período de coleta, quanto a forma de armazenamento afetam o padrão de comportamento espectral das folhas de ipê-amarelo. O tempo de coleta não apresentou diferenças significativas entre 1-2h. As maiores diferenças foram encontradas entre 2-24h após a coleta.

Palavras-chave: Espectrorradiometria; Resposta Espectral; Espécie Arbórea; Análise derivativa.

\section{INTRODUCTION}

Remote sensing is a technique that investigates the interaction between electromagnetic radiation and different types of targets. In vegetation studies, the appliance of this technique allows the acquisition of information on the distribution of different types of vegetation, phenological status, stress conditions, nutrient deficiency, among others.

In the case of Brazilian native species, such as ipê-amarelo, the need for refinement of the remote sensing techniques at laboratory or field level is increasing, justifying the choice of this species. These techniques play an important role in a wide variety of scientific studies and allow monitoring changes in natural areas at different 
scales, as well as differentiate and identify by remote sensing the different types of native vegetation. Therefore, quantifying the influence exerted by the environment in the acquisition of native species spectral behavior data becomes relevant and allows greater control of variables that can affect the final response.

The obtaining data stage in vegetation studies by remote sensors is essential. According to Novo (2010), it can be performed in three different levels: laboratory or field, aerial and orbital. These levels include the study of canopies and/or isolated leaves (extracted or not). In the isolated leaves approach, studies include acquisition of data at laboratory and field levels, aiming the spectral characterization of phenomena directly or indirectly related to plant physiology and morphology (FONSECA et al., 2002).

According to Ponzoni et al. (2012), the parameters that influence the spectral reflectance of leaves refer to their chemical, morphological, physiological and internal humidity composition and each of them exerts a predominant influence in at least three spectral regions of the optical spectrum (visible, near infrared and medium infrared). Thus, we can say that spectroradiometry is an efficient technique for more reliable spectral characterization among plant species, their compositions and humidity conditions.

Laboratory studies of spectral response of plant targets can also be used in conjunction with orbital images in order to obtain field parameters to assist in the interpretation of specific targets in a given period. For that, spectral curves are taken from different species using non-imaging spectroradiometers under laboratory conditions, which are compared with the curves obtained by the remote sensors.

Also called by hyperspectral remote sensing, the spectroradiometry provides advances in different scopes. Scientific efforts have been devoted in the spectral characterization of tree and agricultural species (FONSECA et al., 2002; BRANDELERO et al., 2012; REX et al., 2016; KÄFER et al., 2016; SCHUH et al., 2016) to evaluate the method of collecting spectroradiometric data and its influence on vegetation indices (SCHRODER et al., 2015) and to estimate biochemical and biophysical characteristics of the vegetation (GOERGEN et al., 2015; FOSTER et al., 2016).

In the scope of vegetation spectral characterization studies, few works discuss the influence of collection time and form of storing the leaves from the collection to the place where the radiometric measurements will be performed. Of particular note is the one developed by Souza et al. (1996), who evaluated the influence of time and type of storage on the spectral response of Eucalyptus grandis Hill ex Maiden leaves. It is known that when a leaf is extracted from the plant the senescence process begins, characterized by the degradation of cellular constituents, loss of water, and modifications on structure of foliar mesophyll and, consequently, of its spectral properties (SCHUH et al., 2016).

In this context, the aim of this study is to evaluate the influence of collection time and storage form on the spectral behavior of ipê-amarelo leaves.

\section{MATERIAL AND METHODS}

\section{Characterization and location of species}

The species ipê-amarelo (Handroanthus chrysotrichus Mart. Ex A.DC. Mattos) belongs to the family Bignoniaceae and has important economic relevance due to attractive properties of wood, which is heavy and resistant, allowing its use for noble purposes. In addition, it has ornamental and ecological importance. Morphologically, the species is characterized for presenting a height of 4-5 m, 30-40 cm in diameter, compound leaves (5 leaflets) and yellow flowers (LORENZI, 2008).

The ipê-amarelo used in the collection of samples (leaves) is located near the State Center of Remote Sense and Meteorology (CEPSRM) at the Federal University of Rio Grande do Sul (UFRGS) in Porto Alegre $\mathrm{RS}$ and it is found isolated, therefore, exposed to full sun.

\section{Experimentation and Sampling}

The experiment was conducted with a randomized statistic design in blocks (DBC). Two variation factors were evaluated, the time of collection and the form of storage, consisting of eight treatments, which will be described as follow.

Four samples (leaves) were collected for each treatment corresponding to the N, S, L, and O directions, located in the lower portion of the tree and in the middle portion of the branches, totaling 32 samples. The leaves were stored in properly identified punched paper envelopes. The treatments with thermal storage were packed in styrofoam thermal box, the others were stored in ambient conditions. The treatments were sent to the laboratory where the radiometric readings were performed. 
The samples without thermal storage were measured (radiometric readings) in four different moments after the collection of leaves: 1h (ST0); 2h (ST1); 24h (ST2); 48h (ST3). The same procedure was carried out for the samples with thermal storage, from which radiometric measurements were obtained $1 \mathrm{~h}$ (CT0), 2h (CT1), 24h (CT2) and 48h (CT3) after the collection of ipê-amarelo leaves.

\section{Climatic Conditions}

The three days of collection and the days prior to those defined were characterized by climatic variables, accumulated daily precipitation, temperature and relative humidity, in order to demonstrate the environment conditions of the leaves (Table 1). The daily data were obtained from the National Institute of Meteorology (INMET) of the Meteorological Station of Porto Alegre located at latitude $-30.053536^{\circ}$, longitude of $-51.174766^{\circ}$ and altitude of 41 meters.

Tabela 1. Dados das variáveis climáticas precipitação, temperatura e umidade relativa diária. Table 1. Climatic variables data precipitation, temperature and daily relative humidity.

\begin{tabular}{cccc}
\hline Date & Precipitation $(\mathbf{m m})$ & Temperature $\left({ }^{\circ} \mathbf{C}\right)$ & Relative Humidity (\%) \\
\hline $02 / 06 / 2017$ & 41.9 & 15.34 & 81.25 \\
$03 / 06 / 2017$ & 0 & 15.88 & 80.75 \\
$04 / 06 / 2017$ & 3.2 & 16.66 & 93.25 \\
$05 / 06 / 2017$ & 2.7 & 16.1 & 86 \\
$\mathbf{0 6 / 0 6 / 2 0 1 7} *$ & $\mathbf{2}$ & $\mathbf{1 6 . 2 8}$ & $\mathbf{9 5}$ \\
$\mathbf{0 7 / 0 6 / 2 0 1 7 *}$ & $\mathbf{2 . 1}$ & $\mathbf{1 7 . 0 6}$ & $\mathbf{9 4}$ \\
$\mathbf{0 8 / 0 6 / 2 0 1 7 *}$ & $\mathbf{9 0 . 6}$ & $\mathbf{1 6 . 8 8}$ & $\mathbf{9 0 . 7 5}$ \\
\hline
\end{tabular}

* Indicates the collection dates.

The treatments submitted to thermal storage condition had no external influence, since the styrofoam box represents a homogeneous environment. On the other hand, the treatments in ambient conditions, although they were placed in the same place, they may have been influenced by the environment; however, it is important to highlight that temperature and relative humidity of air on the days of measurements were uniform, as seen in Table 1 .

\section{Radiometric readings}

The radiometric readings were performed at the Radiometry Laboratory of CEPSRM - UFRGS with the support of a spectroradiometer FieldSpec, which has the capacity to record reflectances between 300-2500 nm wavelengths. The readings were taken with the support of leaf clip, the equivalent of an integrating sphere.

The measurements of reflectance of the adaxial face of leaves, which were carefully positioned, were obtained so that only the foliar limb stayed in the sphere's orifice, avoiding the interference of their central vein on themselves. The procedures were the same for all treatments. A microcomputer coupled to the spectroradiometer stored the radiometric readings as they were obtained.

The original data from the measurements were converted to text format (.txt) through the software ASD ViewSpecPro (Version 6.0), in order to make the data format compatible with the other applications and softwares used.

\section{Data analysis}

The data were analyzed and presented in this paper considering three regions of the electromagnetic spectrum: visible region (400-720 nm); near infrared $(720-1100 \mathrm{~nm})$ and medium infrared $(1100-2500 \mathrm{~nm})$ (JENSEN, 2009; PONZONI, et al. 2012).

For the visual analysis of the reflectance curves, graphs containing the spectral response of the treatments in each region were generated. In the derivative analysis, the first and the second derivative were automatically applied by the ASD ViewSpecPro software, and a GAP value of 5 was chosen for correction of imperfections. This technique consists of enhancing features that stand out in the spectral signature of a target, both in reflectance peaks and absorption bands (REX et al. 2016). 
For statistical analysis of data, it was adopted the statistic software R (R CORE TEAM, 2017). The average reflectance factor for each treatment was determined, which corresponded to the arithmetic average of four repetitions per treatments. Ultimately, the data were submitted to analysis of variance (ANOVA) and Tukey's multiple average comparison (HSD- Honestly significant difference) with $95 \%$ of reliability.

\section{RESULTS}

\section{Spectral Behavior}

The spectral responses obtained for each treatment (Figure 1) show that the most pronounced differences occurred in the near infrared and medium infrared regions. Thus, the ST2 and ST3 treatments (both without thermal storage) in the near infrared region exhibited higher reflectances than the other treatments, in addition, they presented smoothness in the curve at the transition point between the visible and near infrared regions.

The aforementioned treatments also showed the lowest reflectances in the visible region and showed lower absorption peaks in the medium infrared region, a region frequently used for detecting hydric stress in vegetation (RODRIGUES et al. 2016).

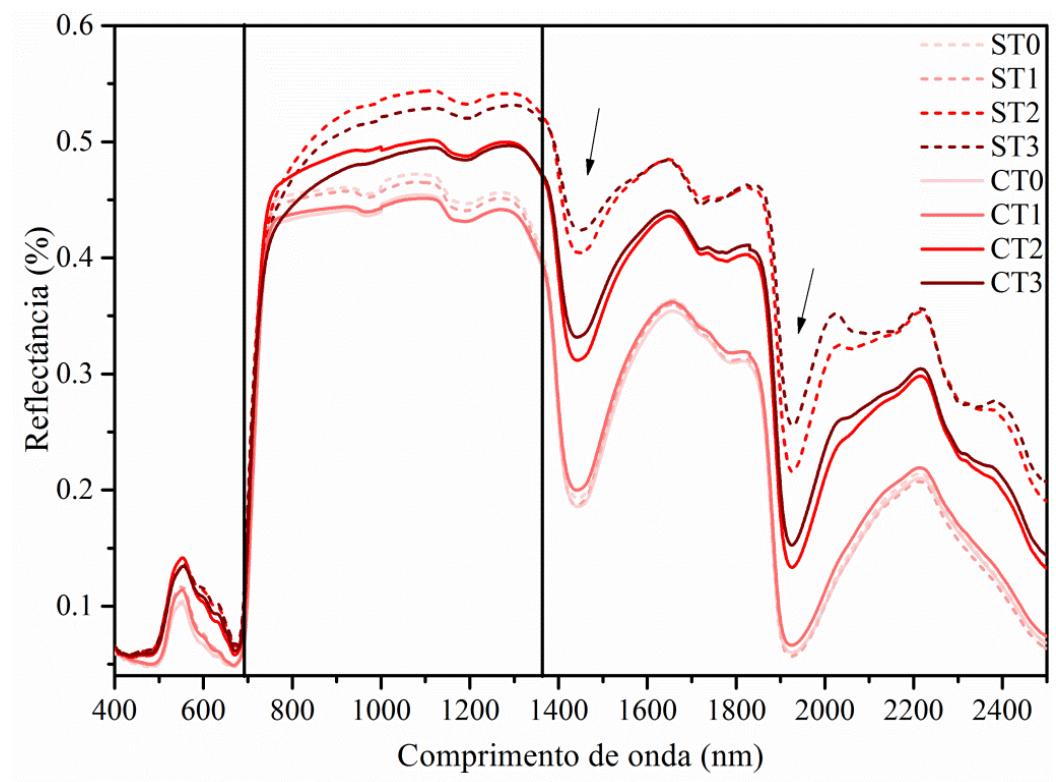

Figura 1. Curvas de reflectância de folhas de ipê-amarelo submetidas a distintos tempos de coleta e formas de armazenamento. As fleshas indicam os pontos de absorção na região do infravermelho médio.

Figure 1. Reflectance curves of ipê-amarelo leaves submitted to different forms of storage and collection time. The arrows indicate the absorption points in the medium infrared region.

\section{Derivative Analysis}

The derivative analysis (Figure 2) allowed to identify larger variations in reflectance and absorption spectra. In general, the first derivative (Figure 2a) shows the highest reflectance and absorption peaks at approximately the same wavelengths in the highest inclination of the original reflectance curve $(500 \mathrm{~nm}, 700 \mathrm{~nm}$, $1,400 \mathrm{~nm}, 1900 \mathrm{~nm})$.

The second derivative (Figure 2b) presents similar behavior, but in a more detailed way. At the wavelength of $700 \mathrm{~nm}$, an absorption peak occurs, which the first derivative was not evidenced. In addition, at approximately $1,400 \mathrm{~nm}$ and 1,900 $\mathrm{nm}$ it is verified the enhancement of reflection peaks, which were shown to be smoothed in the first derivative.

It should be noted as a result of this analysis that at the wavelength of approximately 1,000 nm (near infrared region), a reflectance peak, which could not be seen prior to the application of the first and the second derivative, was observed. In this perspective, the second derivative was able to show this peak, allowing to discriminate the treatments ST0 and CT0. 

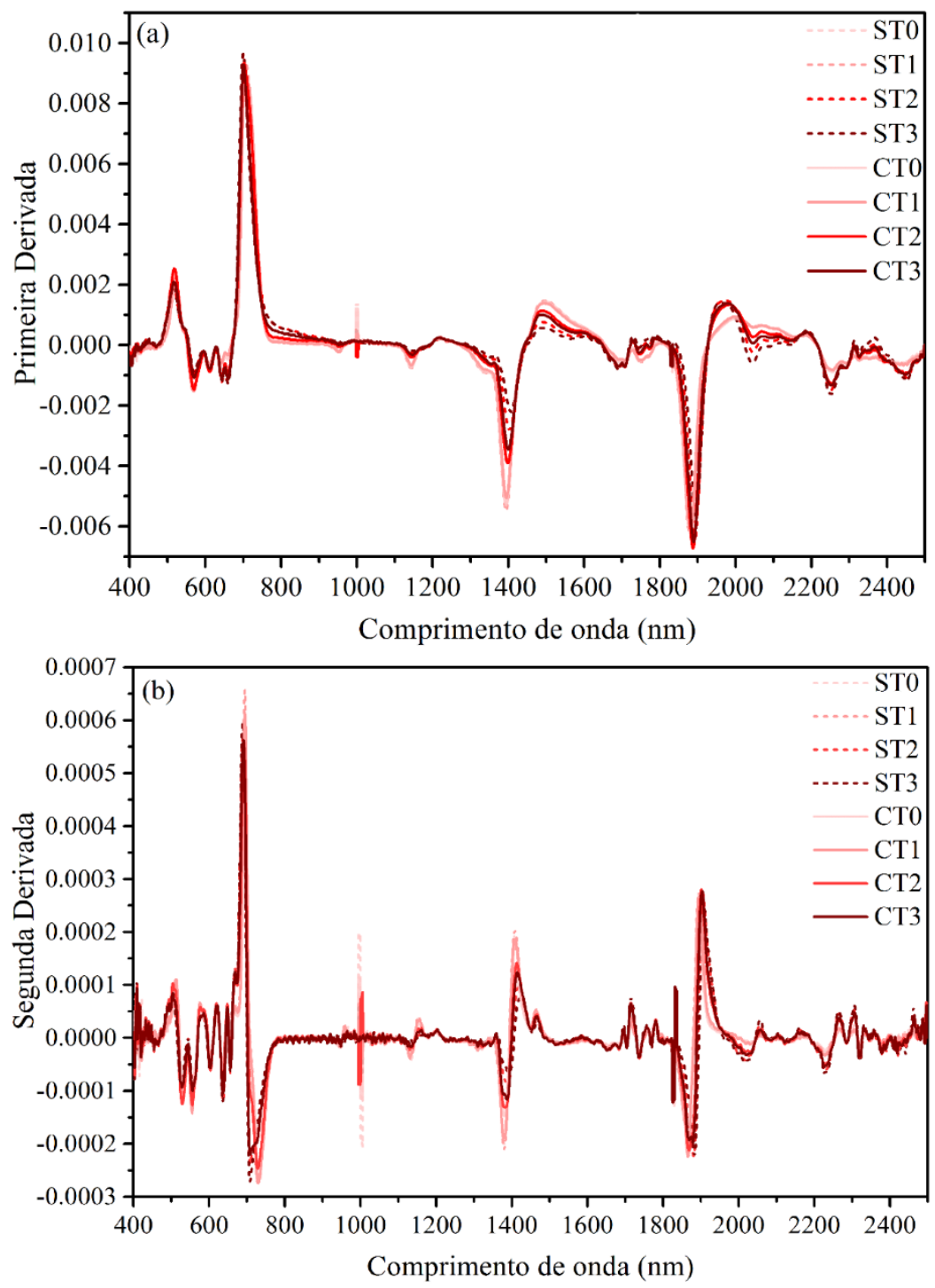

Figura 2. Análise derivativa de curvas de reflectância de folhas de ipê-amarelo submetidas a distintos tempos de coleta e forma de armazenamento. (a)Refere-se à primeira derivada, enquanto (b) refere-se à segunda derivada.

Figure 2. Derivative analysis of ipê-amarelo leaves reflectance curves submitted to different forms of storage and collection time. (a) Refers to the first derivative, while (b) refers to the second derivative.

\section{Statistical analysis}

A statistical analysis using ANOVA allowed to evaluate the null hypothesis (H0), which verifies the existence of homogeneity of variance for the two variation factors considered in this study (time and storage). For the visible region (Table 2), it was possible to identify that there is at least one significant difference between treatments, i. e., at least one moment of acquisition of samples, thus rejecting the hypothesis H0. However, the same was not observed between the blocks, in which it was verified that there is no significant difference between the forms of storage for the visible region, accepting the hypothesis HO. In other words, in this spectral region time significantly affected the spectral response of the ipê-amarelo leaves, whereas the form of storage was not determinant to find significant differences in the spectral curves.

For the near infrared regions (Table 3 ) and medium infrared (Table 4), two sources of variation analyzed showed significant differences. Therefore, the hypothesis $\mathrm{H} 0$ was rejected accepting the alternative hypothesis that there was heterogeneity of variances. Therefore, both time and storage influenced the spectral response of the ipêamarelo leaves. 
Tabela 2. Análise de variância dos diferentes tempos de coleta e forma de armazenamento para a região do visível. Table 2. Variance analysis of different collection times and storage form for the visible region

\begin{tabular}{ccccccc}
\hline Source of variation & SQ & GL & MQ & F & P-Value & F critical \\
\hline Time & 0.395 & 3 & 0.132 & 60.142 & $<2 \mathrm{E}-16^{* * * *}$ & 2.608 \\
Storage & 0.006 & 1 & 0.006 & 2.950 & 0.086. & 3.845 \\
Time x Storage & 0.004 & 3 & 0.001 & 0.654 & 0.581 & 2.608 \\
Residue & 5.607 & 2560 & 0.002 & & & \\
\hline
\end{tabular}

Tabela 3. Análise de variância dos diferentes tempos de coleta e forma de armazenamento para a região do infravermelho próximo.

Table 3. Variance analysis of different collection times and storage form for the near infrared region.

\begin{tabular}{|c|c|c|c|c|c|c|}
\hline Source of variation & SQ & GL & MQ & $\mathbf{F}$ & P-Value & F critical \\
\hline Time & 1.371 & 3 & 0.457 & 528.026 & $<2 \mathrm{E}-16 * * *$ & 2.608 \\
\hline Storage & 0.365 & 1 & 0.365 & 422.020 & $<2 \mathrm{E}-16 * * *$ & 3.845 \\
\hline Time $\mathrm{x}$ Storage & 0.030 & 3 & 0.010 & 11.397 & $1,98 \mathrm{E}-07 * * *$ & 2.608 \\
\hline Residue & 2.624 & 3032 & 0.001 & & & \\
\hline
\end{tabular}

Tabela 4. Análise de variância dos diferentes tempos de coleta e forma de armazenamento para a região do infravermelho médio.

Table 4. Variance analysis of different collection times and storage form for the medium infrared region.

\begin{tabular}{|c|c|c|c|c|c|c|}
\hline Source of variation & SQ & GL & MQ & $\mathbf{F}$ & P-Value & $\mathbf{F}$ \\
\hline Time & 37.258 & 3 & 12.419 & 921.690 & $<2 \mathrm{E}-16 * * *$ & 2.606 \\
\hline Storage & 2.555 & 1 & 2.555 & 189.623 & $<2 \mathrm{E}-16 * * *$ & 3.842 \\
\hline Time $\mathrm{x}$ Storage & 2.536 & 3 & 0.845 & 62.742 & $<2 \mathrm{E}-16 * * *$ & 2.606 \\
\hline Residue & 150.807 & 11192 & 0.013 & & & \\
\hline
\end{tabular}

The Tukey test at 5\% probability allowed to identify which treatments differed from each other in relation to the two sources of variation analyzed. As the blocks did not have statistical differences in the visible region, $i$. e., the use of thermal storage did not influence the spectral response of the curves in this region, only the collection times were analyzed (Table 5). The treatments T0 and T1 did not differ among themselves, the same was observed for treatments T2 and T3. However, treatments with the greatest time difference, such as T0 in comparison to T2 and $\mathrm{T} 3$ and also $\mathrm{T} 1$ in comparison to T2 and T3, differed statistically, demonstrating that between the period of $2 \mathrm{~h}-24 \mathrm{~h}$, significant changes occur in the spectral curves in the ipê-amarelo leaves due to water loss by the leaf.

In the near infrared, in addition to collection time, there was influence of thermal storage on spectral response of curves. Thus, the results of the Tukey test were evaluated considering the interactions of the two variation sources (Table 6). The treatments ST0 and ST1, as well as CT0 and CT1, showed to be equal in the two blocks, indicating that thermal storage does not influence between $1-2 \mathrm{~h}$, since the leaf does not present significant water loss in the period of only $1 \mathrm{~h}$ in this spectral region. 
Tabela 5. Teste de comparação de médias (Tukey) dos diferentes tempos de coleta para região do visível. Table 5. Averages comparison test (Tukey) of different collection times for the visible region.

\begin{tabular}{cc}
\hline $\begin{array}{c}\text { Interactions } \\
\text { (Collection time) }\end{array}$ & Visible \\
\cline { 2 - 2 } & p-adj \\
\hline T1-T0 & $\mathbf{0 . 1 4 4}$ \\
T2-T0 & 0.000 \\
T3-T0 & 0.000 \\
T2-T1 & 0.000 \\
T3-T1 & 0.000 \\
T3-T2 & $\mathbf{0 . 9 5 4}$ \\
\hline
\end{tabular}

Finally, in the medium infrared region the result was similar to that obtained for the near infrared, i. e., there was also no difference between 1-2h. Between blocks, the difference again occurred. The exception remained for treatments ST0 and CT0 and for ST1 and CT1. Additionally, it was possible to observe that the treatments ST2, CT2 and ST3, CT3 did not differ significantly, showing that the water loss that occurred between 24-48h after the collection presented no significant influence on the spectral responses as well. In this region, the greatest differences were found between 2-24h after collection, as well as in the near infrared.

Tabela 6. Teste de comparação de médias (Tukey) dos diferentes tempos de coleta e armazenamento para região do infravermelho próximo (IVP) e infravermelho médio (IVM).

Table 6. Averages comparison test (Tukey) of different collection times and storage form for the near infrared region (NIR) and medium infrared (MIR).

\begin{tabular}{|c|c|c|c|c|c|}
\hline \multirow{2}{*}{ Interactions (Time: storage) } & IVP & IVM & \multirow{2}{*}{ Interactions (Time: storage) } & IVP & IVM \\
\hline & \multicolumn{2}{|c|}{ p-adj } & & \multicolumn{2}{|c|}{ p-adj } \\
\hline ST1-ST0 & 0.482 & 0.919 & CT0-ST2 & 0.000 & 0.000 \\
\hline ST2-ST0 & 0.000 & 0.000 & CT1-ST2 & 0.000 & 0.000 \\
\hline ST3-ST0 & 0.000 & 0.000 & CT2-ST2 & 0.000 & 0.000 \\
\hline CT0-ST0 & 0.000 & 0.737 & CT3-ST2 & 0.000 & 0.000 \\
\hline CT1-ST0 & 0.000 & 1.000 & CT0-ST3 & 0.000 & 0.000 \\
\hline CT2-ST0 & 0.000 & 0.000 & CT1-ST3 & 0.000 & 0.000 \\
\hline CT3-ST0 & 0.001 & 0.000 & CT2-ST3 & 0.000 & 0.000 \\
\hline ST2-ST1 & 0.000 & 0.000 & CT3-ST3 & 0.000 & 0.000 \\
\hline ST3-ST1 & 0.000 & 0.000 & CT1-CT0 & 0.961 & 0.634 \\
\hline CT0-ST1 & 0.000 & 1.000 & СТ2-СТ0 & 0.000 & 0.000 \\
\hline CT1-ST1 & 0.000 & 0.858 & СТ3-СТ0 & 0.000 & 0.000 \\
\hline CT2-ST1 & 0.000 & 0.000 & CT2-CT1 & 0.000 & 0.000 \\
\hline CT3-ST1 & 0.000 & 0.000 & CT3-CT1 & 0.000 & 0.000 \\
\hline ST3-ST2 & 0.000 & 0.874 & CT3-CT2 & 0.000 & 0.566 \\
\hline
\end{tabular}

\section{DISCUSSION}

\section{Spectral Behavior}

The indicative of hydric stress, indirectly evaluated here from the collection time of plant material, are based on spectral behavior of vegetation that is acquired according to composition, morphology and internal structure of the leaves (PONZONI et al., 2012). Hence, the behavior of higher reflectances in IVP region for ST2 and ST3 treatments and smoothing at the transition point between visible and near infrared regions are typical of leaves in hydric stress, which have lost vegetative vigour and, consequently, verticality of red border (REX et al., 2016), as the water decreased. 
With low reflectance in the near infrared region of CT0 and CT1 treatments, which was even lower than that presented by ST0 and ST1 treatments, it is evidenced that the thermal storage allowed a delay in the loss of humidity by the leaves, which influenced the spectral behavior of treatments curves. On this, Souza et al. (1996) found that the storage of Eucalyptus grandis leaves in plastic bags (with dampened cotton) allowed better preservation of internal structures of leaves compared to storage under normal environmental conditions. The same occurs in this wavelength range with CT2 and CT3 treatments curves when compared to ST2 and ST3 treatments, reinforcing the hypothesis cited. Besides, it is possible to highlight the behavior of CT2 curve, in which the verticality of red border was maintained in comparison to the ST2 curve.

\section{Derivative Analysis}

For Rudorff et al. (2007), the application of derivative analysis has, as main advantage, the production of hyperspectral data less sensitive to components that cause undesirable variations, which behave as additive constants and spectrally independents over the spectral range of interest. The trend of higher reflectance values at the wavelengths of $500 \mathrm{~nm}, 700 \mathrm{~nm}, 1400 \mathrm{~nm}, 1900 \mathrm{~nm}$, ascertained from the derivative analysis was also verified by Ennes et al. (2010) when evaluating the spectral characterization of water reservoir using derivative analysis. The authors state that after applying the first and second derivative, it was possible to obtain a spectral curve that contained only features associated with the presence of chlorophyll, which indicates that these wavelengths can be analyzed discreetly.

As already mentioned, the first derivative (Figure 2a) was able to highlight the treatments ST0, CT0, CT1 and CT2 at $1000 \mathrm{~nm}$, while the second derivative allowed better detailing of these peaks. This can indicate that at this wavelength the subtler variations occur between 1-2h after the leaf is removed from the tree (referring to ST0, CT0 and CT1). In the first derivative, CT2 treatment shows negative value and represents the largest variation referring to the period between 2-24h. In the second derivative graph (Figure 2b), the same treatment appears in greater proportions in both negative and positive axis, which is explained by Goodin (1993), who found that for second derivative curves, the results show an enhancement of characteristic features of the first derivative curves. Although it is the only treatment referring to the 2-24 hour period that is emphasized at this wavelength, it is important to note that it refers to a thermal storage treatment, thus its response may be closer to the ones of treatments without storage and with shorter collection time.

\section{Statistical analysis}

The non-differentiation statistic between blocks in visible region disagrees with the results found by Souza et al. (1996). The authors evaluated the spectral regions of visible and near infrared discreetly and verified that the form of storage for eucalyptus leaves (Eucalyptus grandis) presented significant differences only in 450$520 \mathrm{~nm}$ and 630-690 $\mathrm{nm}$ (visible region). However, it is important to mention that the assessed form of storage (plastic bags) by the authors is distinguished from the form here tested.

The significant change between the 2-24 hour period that was possible to be seen for the visible region (Table 4), was also identified by Souza et al. (1996) for leaves of Eucalyptus grandis, time began to exert significant influence after 23 and 29 hours. As for leaves of Erythrina crista-galli L., the collection time in the visible region presented the greatest differences after 72 hours of collection (GÖERGEN et al., 2009), evidencing that the loss of water varies significantly according to the evaluated species, which reinforces the importance of forest species characterization by spectroradiometry in order to find possible similarities between species.

As for near and medium infrared regions (Table 5), Sousa et al. (1996) analyzed the time of collection for the species Eucalyptus grandis, the authors found that in near infrared region, time only began to influence after $3 \mathrm{~h}$ from the extraction of the tree leaves. The same is observed in this study for near and medium infrared. Nevertheless, it is possible to notice that the region in which time and storage have the greatest number of variations is the near infrared, since the table shows that the storage variable does not exhibit determinant results in the medium infrared region. Thus, it is evidenced that the water loss by the leaf in a first moment causes more effect in the internal structure of leaves.

\section{CONCLUSIONS}

- The collection time and the form of storage affect the spectral behavior pattern of ipê-amarelo leaves.

- Thermal storage can delay the process of senescence of leaves between 24-48h. This process generates visual and statistical differences, which are significant in the spectral behavior of ipê-amarelo leaves in near and medium infrared regions. 
- The collection time did not show significant differences between $1-2 \mathrm{~h}$ before the measurement by the spectroradiometer in the three spectral regions evaluated.

- The largest differences occurred between 2-24h. Therefore, future studies should be conducted considering more frequent collection times between $2 \mathrm{~h}-24 \mathrm{~h}$ and other forms of storage not evaluated in this paper.

- The derivative analysis was satisfactory. At the wavelength of $1,000 \mathrm{~nm}$, the first derivative may have highlighted changes occurred within the first few hours after collection.

\section{ACKNOWLEDGMENTS}

The authors would like to thank the Coordination of Personnel Improvement of Higher Education (CAPES) and the National Council of Scientific and Technological Development (CNPq) for their financial support and the State Center of Research in Remote Sense and Meteorology of the Federal University of Rio Grande do Sul by the physical structure and the spectroradiometer used to carry out this research.

\section{REFERENCES}

BRANDELERO, C.; BERRA, E. F.; BACKES, K. S.; PEREIRA, R. S.; BRUN, E. J. Espectrorradiometria na região do visível e do infravermelho próximo em povoamento de Eucalyptus grandis Hill ex Maiden. Ciência Florestal, v. 22, n. 1, p. 215-22, 2012.

ERNNES, R.; GALO, M. L. B. T.; TACHIBANA, V. M T. Caracterização espectral da água do reservatório de Itupararanga, SP, a partir de imagens hiperespectrais Hyperion e análise derivativa. Boletim de Ciências Geodésicas, v. 16, n. 1, p. 86-104, 2010.

FOSTER, A. J.; KAKANI, V. G.; GE, L.; GREGORY, M.; MOSALI, J. Discriminant analysis of nitrogen treatments in switchgrass and high biomass sorghum using leaf and canopy-scale reflectance spectroscopy. International Journal of Remote Sensing, v. 37, n. 10, p. 2252-2279, 2016.

FONSECA, E. L.; ROSA, L. M.; FONTANA, D. C. Caracterização espectral de Paspalum notatum em diferentes níveis de adubação nitrogenada. Pesquisa Agropecuária Brasileira, v. 37, n. 3, p. 365-371, 2002.

FOUNDATION FOR STATISTICAL COMPUTING. R Core Team. R: A language and environment for statistical computing. Vienna, Austria, 2017. Disponível em: 〈https://www.R-project.org/>. Acesso em: 06 set. 2017.

GOODIN, D. G.; HAN, L. FRASER, R. N.; RUNDQUIST, C.; STEBBINS, W. A.; SCHALLES, J. F. Analysis of suspended solids in water using remotely sensed high resolution derivate spectra. Photogrammetric Engineering and Remote Sensing, Manhattan, v. 59, n. 4, p. 505-510, 1993.

GÖERGEN, L. C. de G; SOARES, J. C. W; BERRA, E. F.; BRANDELERO, C.; PEREIRA, R. S. Índices espectrais para avaliação da dinâmica sazonal de clorofilas em folhas de Eucalyptus grandis. Pesquisa Florestal Brasileira, v. 35, n. 82, p. 55-61, 2015.

JENSEN, J. R. Sensoriamento remoto do ambiente: uma perspectiva em recursos terrestres. São José dos Campos, SP: Parêntese. 2 ed. 2009, 672 p.

KÄFER, P. S.; REX, F. E.; SANTOS, M.; SEBEM, R. Caracterização espectral e NDVI de espécies florestais das famílias Fabaceae, Myrtaceae, Rutaceae e Salicaceae. Enciclopédia Biosfera, v. 13, n. 23, p. 262-275, 2016.

LORENZI, H. Árvores Brasileiras: manual de identificação e cultivo de plantas arbóreas do Brasil, v. 1, 5. Ed.Nova Odessa, SP: Instituto Plantarum. 2008, 384 p.

NOVO, E. M. L. Sensoriamento remoto. Princípios e aplicações. São Paulo. Editora Edgard Blucher. 4 ed. 2010.

PONZONI, F. J.; SHIMABUKURO, Y. E.; KUPLICH, T. M. Sensoriamento Remoto da Vegetação. São Paulo: Oficina de Texto. 2 ed. 2012, 176 p.

REX, F. E.; KÄFER, P. S.; SANTOS, M.; SEBEM, E. Análise derivativa de dados de reflectância obtidos por espectrorradiometria para caracterização de espécies arbóreas. Enciclopédia Biosfera, v. 13, p. 26-38, 2016. 
RUDORFF, C. M.; NOVO, E. M. L. M.; GALVÃO, L.S.; PEREIRA FILHO, W. Análise derivativa de dados hiperespectrais medidos em nível de campo e orbital para caracterizar a composição de águas opticamente complexas na Amazônia. Acta Amazônica, v. 37, n. 2, p. 269-280, 2007.

SCHRODER, T.; PEREIRA, R. S.; ZIMMERMANN, A. P. L.; REDIN, C. G.; MACHADO, L. M.; FLECK, M. D.; ROCHA, N. S. Influência de métodos de coleta de dados espectrorradiométricos sob índices de vegetação em eucalipto. Revista Eletrônica em Gestão, Educação e Tecnologia Ambiental, v. 19, n. 3, p. 690-701, 2015.

SCHUH, M. S.; FAVARIN, J. A. S.; DESSBESELL, L.; SILVA, E. A.; GOERGEN, L. C. G.; PEREIRA, R. S. GALVÍNCIO, J. D. Análise temporal do vigor vegetativo por meio de espectrorradiometria. Revista Brasileira de Geografia Física. v. 9, n. 6, p. 1888-1894, 2016.

SOUSA, C. L.; RIBEIRO, M. C.; PONZONI, F. J. Influência do tempo e do tipo de armazenamento na reflectância espectral de folhas de Eucalyptus grandis "ex-situ". Revista Árvore, Viçosa - MG, v. 20, n. 2, p. 247-253, 1996.

RODRIGUES, T. W. P.; GUIMARÃES, U. S.; ROTTA, L. H. S.; WATANABLE, F. S. Y.; ALCÂNTRA, E.; IMAI, N. N. Delineamento amostral em reservatórios utilizando imagens Landsat-8/OLI: Um estudo de caso no reservatório de Nova Avanhandava (Estado de São Paulo, Brasil). Boletim de Ciências Geodésicas, Curitiba, v. 22, n. 2, p. 303-323, 2016. 